\title{
Melatonin Mediated Regulation of Drought Stress: Physiological and Molecular Aspects
}

\author{
Anket Sharma *(i) and Bingsong Zheng *(i) \\ State Key Laboratory of Subtropical Silviculture, Zhejiang A\&F University, Hangzhou 311300, China \\ * Correspondence: anketsharma@gmail.com or anketsharma@zafu.edu.cn (A.S.); bszheng@zafu.edu.cn (B.Z.); \\ Tel.: +86-(0)571-63730936 (B.Z.)
}

Received: 11 June 2019; Accepted: 25 June 2019; Published: 26 June 2019

\begin{abstract}
Drought stress adversely effects physiological and biochemical processes of plants, leading to a reduction in plant productivity. Plants try to protect themselves via activation of their internal defense system, but severe drought causes dysfunction of this defense system. The imbalance between generation and scavenging of reactive oxygen species (ROS) leads to oxidative stress. Melatonin, a multifunctional molecule, has the potential to protect plants from the adverse effects of drought stress by enhancing the ROS scavenging efficiency. It helps in protection of photosynthetic apparatus and reduction of drought induced oxidative stress. Melatonin regulates plant processes at a molecular level, which results in providing better resistance against drought stress. In this review, the authors have discussed various physiological and molecular aspects regulated by melatonin in plants under drought conditions, along with their underlying mechanisms.
\end{abstract}

Keywords: abiotic stress; plant stress physiology; oxidative stress; water deficit conditions; water stress

\section{Introduction}

In the present era, water scarcity is one of the main environmental challenges for plants, which has negative impacts on their growth and development [1,2]. The reduction of water availability to plants causes physiological imbalances which ultimately reduces plant productivity [3]. The impact of drought stress on the physiological responses of plants is dependent upon the level of drought, its exposure time and the growth stage of plants [4]. Drought stress induces phytotoxicity by enhancing accumulation of reactive oxygen species (ROS) in the plant cells, which is mainly due to the imbalance between ROS generation and their scavenging [1,5]. Increased concentrations of ROS during drought conditions negatively affect the photosynthetic reactions by disrupting the photosynthetic apparatus, including reaction centers and chloroplast structures [6-9]. Furthermore, enhanced ROS accumulation favors the degradation of chlorophyll molecules and finally declines the photosynthetic performance of plants under water deficit conditions [10,11].

As plants are exposed to various biotic and abiotic factors, they possess an inbuilt system, known as antioxidant system, to regulate the biological processes under adverse environmental conditions. This antioxidant system is comprised of enzymatic and non-enzymatic antioxidants, which work in a systematic manner to control the levels of ROS in plant cells [12]. However, under severe stress conditions, such as high drought levels, this antioxidant system is disrupted, leading to an imbalance in redox homeostasis in plant cells [13-15].

Plant growth regulators are multifunctional molecules which are well known for their physiological functions in plants [16-19]. These molecules also play an important role in providing resistance to plants growing under abiotic stresses, such as heavy metals, temperature, pesticides and drought [20-26]. Melatonin is a growth regulator which also confers stress tolerance to plants growing under adverse 
conditions such as drought $[6,27,28]$. Melatonin regulates the biology of plants by modulating various physiological, biochemical and molecular processes and ultimately enhances resistance in plants to withstand drought conditions $[29,30]$. The regulation of photosynthetic machinery and the anti-oxidative defense system are the main physiological processes controlled by melatonin under water deficit conditions [31,32]. In the recent past, considerable research has been undertaken to explore the effects of this multifunctional molecule in plants under abiotic stress conditions [33-35]. However, as compared to other stresses, drought stress has been less studied and there is a need to have comprehensive knowledge about the exact mechanisms behind the regulation of melatonin mediated drought tolerance. Thus, the main objective of the current review is to discuss the advanced developments undertaken in the recent past which explore the melatonin-mediated drought tolerance in plants. For a better understanding of the topic, the authors started by discussing the impact of drought on plant biology, followed by an examination of the various physiological roles of melatonin. Following this, the mechanisms behind melatonin modulated physiological and molecular aspects were discussed, including photosynthetic processes, regulation of oxidative stress and other important biological mechanisms in plants under drought conditions.

\section{Drought Stress and its Impacts on Plant Physiology}

Plants growing under water deficit conditions face many challenges at the biochemical and molecular level which ultimately causes hindrance to plant's growth and yield [36,37]. Drought stress causes a decline in photosynthesis by disturbing the mechanism of light harvesting and its utilization, negatively impacting the metabolism of photosynthetic pigments, which declines the RuBisCo function accompanied by disruption of the photosynthetic apparatus [38-40]. Disruption of the chloroplast structure also negatively affects photosynthetic performance of plants growing under drought conditions [6,30]. Drought negatively influences the intercellular $\mathrm{CO}_{2}$ levels which favors the generation of reduced photosynthetic electron transport constituents, resulting in enhanced generation of ROS, which causes disruption of the photosynthetic apparatus [41]. Disruption of the photosynthetic apparatus due to drought leads to a reduction of the photosynthetic rate, stomatal conductance, transpiration rate, photochemical efficiency of PSII and photosynthetic electron transport rate [6,29,42]. Stomatal closure during water deficit conditions is regulated by the enhanced endogenous levels of abscisic acid (ABA), which acts as a signaling molecule to modulate a cascade of various physiological and molecular processes. This enhanced biosynthesis of ABA is due to the up regulation of the ABA biosynthetic gene NCED3 (9-cis-epoxycarotenoid dioxygenase 3) [43,44]. The expression of histone H1-S is enhanced under drought stress and this protein promotes the closure of stomata [45,46]. Moreover, ABA also acts as primary messenger for cell signaling pathways which further accelerates the generation of ROS, followed by increased accumulation of cytosolic $\mathrm{Ca}^{2+}$ which acts as secondary messenger, stimulating other signaling cascades to regulate plant processes at the molecular level [43].

Drought stress decreases water potential and the relative water content of plants [47-49]. Declined water potential further causes a reduction in the uptake of various essential minerals, such as nitrogen, phosphorous and potassium $[37,50]$. Water deficit conditions have a negative impact on the nitrogen transporters and nitrogen metabolism. It is due to the down-regulation of genes, such as $A M T$ (ammonium transporter), NRT (nitrate transporter), NR (nitrate reductase), NiR (nitrite reductase), GS (glutamine synthetase) and GOGAT (glutamate synthase), under drought stress [51]. Reduced nutrient uptake is also accompanied by reduced efficiency of their translocation to the target sites in plants growing under water deficit conditions [52]. Moreover, declined root growth in soils having low water also negatively affects the efficiency of the nutrient uptake [53].

Drought stress causes an imbalance between the production of ROS and their scavenging, leading to oxidative stress in plant cells [36]. This ROS scavenging failure leads to the over accumulation of ROS in plant cells, resulting in oxidation of proteins, peroxidation of lipid membranes and damage to genetic material $[54,55]$. Increased ROS levels also cause a reduction in fixation efficiency of $\mathrm{CO}_{2}$ accompanied by enhanced photorespiration [56]. To counterattack the negative effects of drought 
induced oxidative stress, plant's enzymatic and non-enzymatic antioxidants work together to provide drought resistance [12,36]. However, severe drought causes an imbalance in redox homeostasis, which is mainly due to the declined efficiency of the anti-oxidative defense system. For example, activities of enzymes, such as catalase (CAT) and ascorbate peroxidase (APX), were reported to decrease under high drought conditions [57]. The production of various osmolytes, such as soluble sugars, proline and glycine-betaine, also become enhanced, resulting in more accumulation of these compounds which act as osmoprotectants under drought stress [58,59]. These osmolytes assist in maintaining the leaf turgor which results in efficient stomatal conductance followed by better $\mathrm{CO}_{2}$ intake by leaves and water uptake by roots $[60,61]$. The enhanced osmoprotectant accumulation is due to the up-regulation of genes involved in biosynthesis of osmolytes, aquaporins, LEA proteins, accompanied by regulation of various important transcription factors [45]. Figure 1 gives an overview on various responses of plants under drought stress.

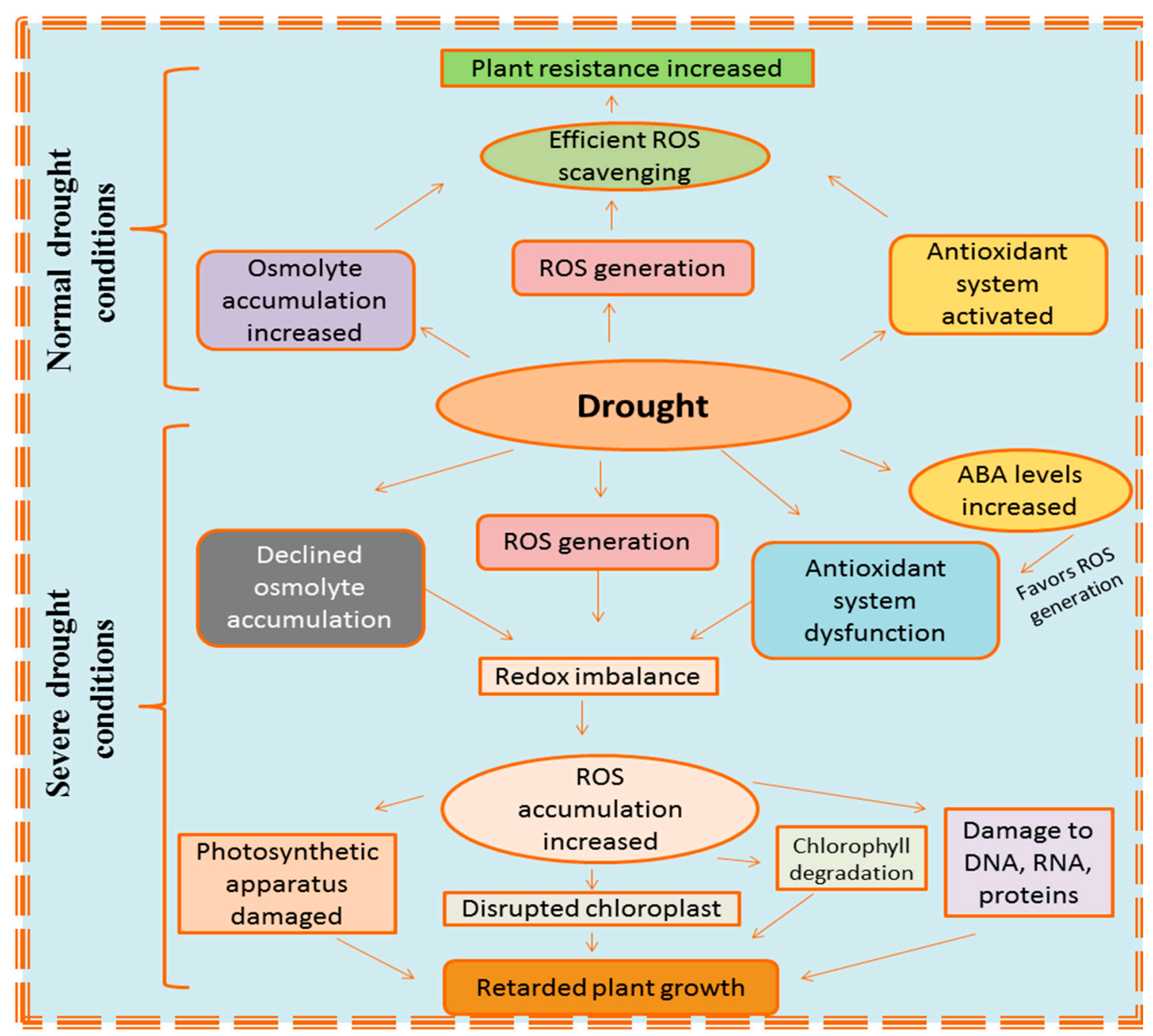

Figure 1. Diagrammatic sketch explaining various responses of plants under drought conditions.

\section{Role of Melatonin in Regulation of Plant Physiology}

Melatonin is a growth regulator known for its important roles in the regulation of plant growth and development $[62,63]$. It regulates plant's developmental processes starting from the seed germination and has been considered to show similar effects, such as auxins, during the process of etiolation [64]. It is also believed that melatonin and auxins can have a co-regulatory impact on plant growth [65]. The concentration of melatonin also acts as a rate limiting step in the regulation of physiological processes. 
At lower concentrations, it promotes the growth, whereas at higher concentrations, it has inhibitory effects [66]. Melatonin also regulates the important plant processes such as morphogenesis, rhizogenesis and caulogenesis $[67,68]$. Melatonin positively regulates the growth of roots. This was supported by studies carried out on genetically modified rice in which gene encoding serotonin-N-acetyltransferase (SNAT) was over expressed. The over expression of SNAT resulted in a manifold enhancement of endogenous melatonin levels accompanied by a significant increment of rice seedling root growth [69]. In plant roots, melatonin also induces the formation of root primodia from pericycle cells [70-73]. Transcriptomic studies carried out on cucumber roots established that melatonin treatment up-regulated 121 genes, and down-regulated 196 genes. This transcriptomic regulation enhanced the plant growth by increasing the total count of lateral roots [74]. This melatonin mediated root growth in plants is supposed to be regulated in an auxin dependent manner [75,76].

Melatonin also promotes plant growth by enhancing the efficiency of carbon assimilation [77,78]. Moreover, another fact favoring the improved photosynthesis is the stimulated stomatal conductance after melatonin application [6]. Photochemical efficiency of PSII is also stimulated by melatonin, enhancing the overall photosynthesis [42,79]. Moreover, melatonin also boosts the accumulation of RuBisCO along with enhanced total nitrogen and protein content [80]. Melatonin mediated enhancement in photosynthesis is also accompanied by the reduced catabolism of chlorophyll molecules and down-regulation of genes favoring the process of senescence [81]. A delay in senescence in melatonin treated plants is favored by low $\mathrm{H}_{2} \mathrm{O}_{2}$ levels accompanied by high APX activity. Additionally, melatonin regulates the ascorbate-glutathione cycle, resulting in more accumulation of ascorbate and glutathione, accompanied by low levels of dehydroascorbate and oxidized glutathione [82]. Seeds treated with melatonin before sowing resulted in improved germination and vigor plants [77,83]. This melatonin seed priming has been followed by overall better vegetative and reproductive growth of plants leading to improvement in yields [84,85]. In addition to other physiological processes, melatonin also regulates fruit ripening. In tomatoes, melatonin has been observed to trigger fruit ripening by stimulating ethylene biosynthesis accompanied by the up-regulation of transcripts involved in ethylene signalling pathways [86]. Moreover, melatonin also regulates the biosynthesis of anthocyanin and proteins related to the process of fruit ripening [87].

\section{Melatonin Mediated Regulation of Plant Biology under Drought Stress}

\subsection{Regulation of Photosynthetic Response}

Melatonin protects the photosynthetic apparatus from the deleterious effects of drought, resulting in the recovery of photosynthetic efficiency of plants [6,51]. Melatonin prevents the degradation of the chlorophyll molecule during drought stress and improves the photosynthesis, transpiration and stomatal conductance $[51,88]$. Chlorophyll degradation is catalyzed by enzymes such as, chlorophyllase (Chlase), pheophytinase (PPH) and chlorophyll degrading peroxidase (Chl-PRX) [11,89-93]. The reduction in degradation of chlorophyll after melatonin treatment is due to the down-regulation of genes including Chlase, PPH and Chl-PRX [11]. Additionally, melatonin also recovers the content of photosynthetic accessory pigments, such as carotenoids under drought stress [31]. Another enzyme, pheophorbide-a-oxygenase (PAO), is involved in the chlorophyll metabolism. Melatonin down-regulates the transcript levels of $P A O$, resulting in reducing the rate of chlorophyll degradation under drought conditions [32].

Enhanced photosynthetic rate by melatonin is accompanied by improved photochemical efficiency (Fv/Fm) of photosystem II (PSII) along with a better photosynthetic electron transport rate (ETR) [31,70]. Non photochemical quenching is enhanced under drought stress and has a negative impact on photosynthetic efficiency. However, melatonin application to drought stressed plants helps in recovering photosynthetic performance [32]. The enlargement of the leaf area in melatonin treated plants provides another reason for the better photosynthetic efficiency under water deficit conditions [29]. 
The main reason behind the melatonin mediated improvement of photosynthesis in drought stress is that melatonin protects the chloroplast structures in leaves from oxidative damage [6,30]. During water deficit conditions, the length of chloroplast decreases gradually, which is accompanied by a disruption of the membrane, stroma lamellae, grana and thylakoids. However, melatonin treatment prevents all these ill effects of drought on the chloroplast structure [6]. The better relative water content in drought stresses leaves after melatonin treatment which further favors the protection of chloroplast structures [94]. The better water potential in melatonin treated plants under drought stress [29] can also aid in chlorophyll protection. Moreover, the length of stomata, and the recovery in the shape of palisade tissue accompanied by less damage to spongy tissue cells also contributes towards improved photosynthesis of drought stressed plants after melatonin treatment [6]. Additionally, melatonin also aids in maintaining the cell turgor which enhances the capacity of stomatal opening and conductance [6]. This increased stomatal conductance helps in better movement of water and $\mathrm{CO}_{2}$, and ultimately favors the photosynthesis in melatonin treated plants [30]. All these processes are further favored by melatonin regulated water balance in the mesophyll cells along with their turgor pressure regulation [30,95]. Moreover, it has also been suggested that in Malus, melatonin down-regulated a key gene of ABA biosynthetic pathway (MdNCED3) and simultaneously up-regulated the transcript levels of genes involved in degradation of ABA (MdCYP707A1 and MdCYP707A1). This molecular response was accompanied by an anti-oxidative response and efficient scavenging of $\mathrm{H}_{2} \mathrm{O}_{2}$. Both of these mechanisms are believed to work in a synergistic manner to result in better stomatal function [96]. Recently, it has been established that melatonin regulated the carbon fixation pathway at a molecular level, which resulted in the recovery of the photosynthetic performance of plants growing under drought stress [31]. Melatonin up-regulates the transcript levels of various key enzymes of the carbon fixation pathway, such as RUBISCO (ribulose bisphosphate carboxylase), PGK (phosphoglycerate kinase), GAPA (glyceraldehyde-3-phosphate dehydrogenase), FBA (fructose-bisphosphate aldolase), FBP (fructose-1,6-bisphosphatase), TIM (triosephosphate isomerase), SEBP (sedoheptulose-1,7-bisphosphatase), TKT (transketolase), RPI (ribose 5-phosphate isomerase) and RPK (phosphoribulokinase) [31]. Table 1 summarizes the effect of melatonin on photosynthetic parameters of plants under drought stress.

Table 1. Summary table explaining the effect of exogenous applied melatonin on various photosynthetic parameters under drought stress.

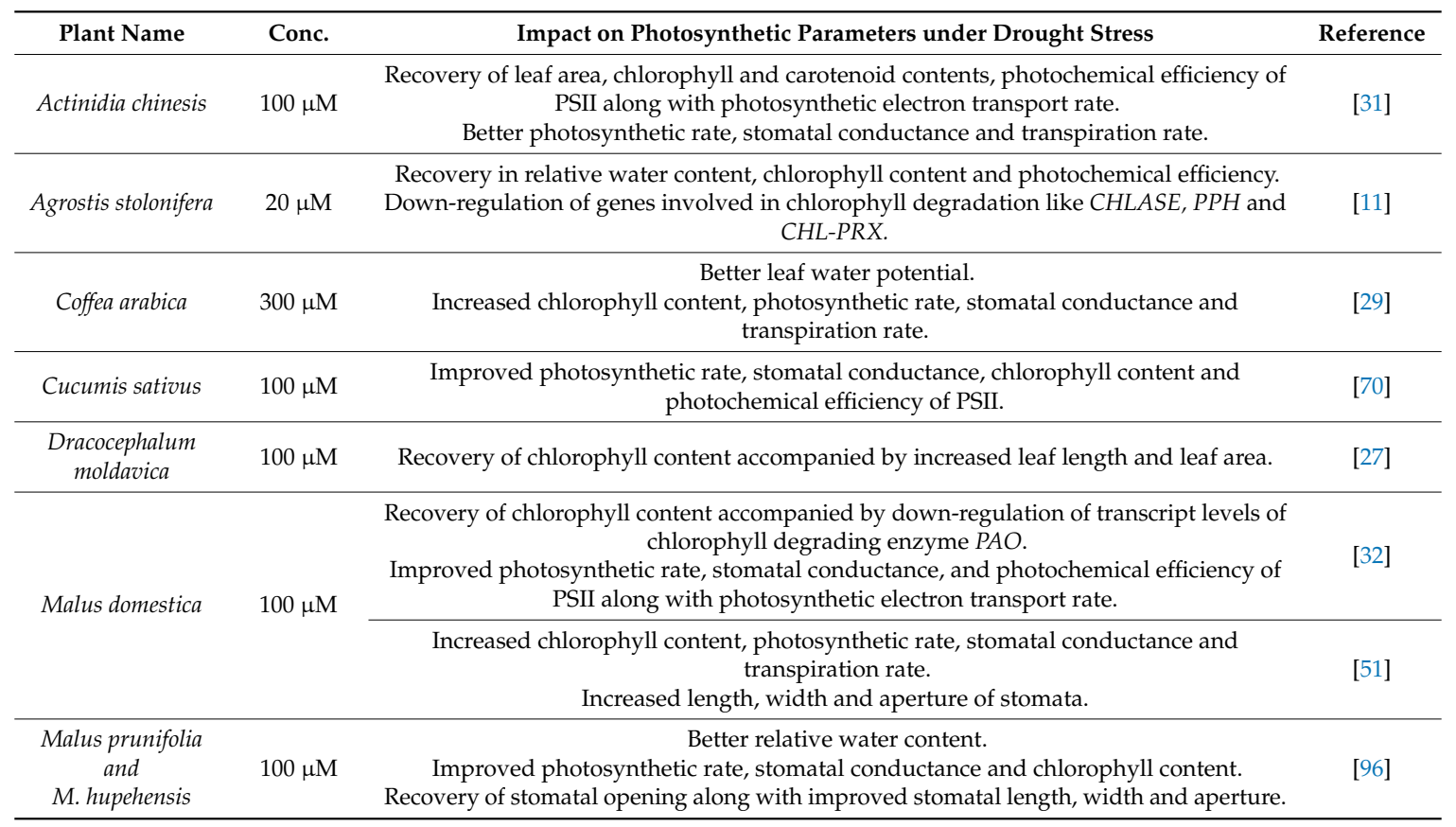


Table 1. Cont.

\begin{tabular}{|c|c|c|c|}
\hline Plant Name & Conc. & Impact on Photosynthetic Parameters under Drought Stress & Reference \\
\hline \multirow{2}{*}{$\begin{array}{l}\text { Solanum } \\
\text { lycopersicum }\end{array}$} & $200 \mu \mathrm{M}$ & Recovery of chlorophyll content. & [88] \\
\hline & $100 \mu \mathrm{M}$ & Better cell wall stability accompanied by less leaching of chlorophyll molecules. & [97] \\
\hline Triticum aestivum & $100 \mu \mathrm{M}$ & $\begin{array}{l}\text { Recovery of chloroplast apparatus, photosynthetic rate, stomatal conductance, } \\
\text { transpiration rate and photochemical efficiency of PSII. }\end{array}$ & [30] \\
\hline \multirow[b]{2}{*}{ Zea mays } & $1 \mathrm{mM}$ & Recovery of photochemical efficiency of PSII. & [94] \\
\hline & $100 \mu \mathrm{M}$ & $\begin{array}{l}\text { Better leaf area accompanied by recovery in chlorophyll content, photosynthetic rate, } \\
\text { stomatal conductance and transpiration rate. } \\
\text { Improved water potential, photochemical efficiency of PSII along with photosynthetic } \\
\text { electron transport rate. }\end{array}$ & [42] \\
\hline
\end{tabular}

Chlase, chlorophyllase; PPH, pheophytinase; Chl-PRX, chlorophyll degrading peroxidase, PAO, pheophorbide-aoxygenase; PSII, photosystem II.

\subsection{Regulation of Oxidative Stress and Antioxidative Defense System}

\subsubsection{Impact on ROS Accumulation}

Melatonin protects plants from the ill effects of drought induced oxidative stress by enhancing the ROS scavenging efficiency. This triggered ROS scavenging is due the melatonin stimulated anti-oxidative defense system of plants growing under drought conditions $[6,29,30,32]$. The drought induced generation of superoxide anions in plant cells is controlled by melatonin, either by enhancing the scavenging or by controlling the production of superoxide anions $[6,98,99]$. Moreover, scavenging efficiency of $\mathrm{H}_{2} \mathrm{O}_{2}$ is also enhanced by melatonin in plants growing under drought stress $[6,70,96]$. This is followed by enhanced detoxification of harmful hydroxyl radicals and other aldehydes involved in the induction of oxidative stress [27,70]. Melatonin also regulates the ascorbate-glutathione cycle and triggers the direct scavenging of ROS, such as $\mathrm{H}_{2} \mathrm{O}_{2}$ [32]. Melatonin mediated efficient $\mathrm{ROS}$ scavenging in the plants under drought stress leads to protection of plant cell walls. This fact is supported by the reduced levels of MDA content and decline in electrolyte leakage in melatonin treated plants under water deficit conditions $[11,27,31]$.

Due to water scarcity in plant cells, biosynthesis of ABA is enhanced, resulting in accumulation of more ABA than the normal conditions. These enhanced ABA levels favor the generation of ROS, causing oxidative stress in terms of lipid peroxidation, electrolyte leakage and cause breakdown of chlorophyll molecules [100]. However, molecular studies on melatonin treated plants under drought stress revealed that a reduction in ROS levels was also accompanied by declined ABA accumulation. This declined $\mathrm{ABA}$ concentration was due to the melatonin mediated down-regulation of genes responsible for $\mathrm{ABA}$ biosynthesis and simultaneously up-regulation of genes involved in ABA catabolism [96]. Moreover, it is also believed that melatonin regulates the scavenging/generation of ROS via CK-signaling and both of melatonin and CK work synergistically to regulate drought induced oxidative stress in plant cells [11]. All of these above mentioned facts were further supported by studies in which the overexpression of TaCOMT (gene involved in melatonin biosynthesis) in Arabidopsis were subjected to water deficit conditions. In comparison to non-transgenic plants, overexpressing this gene resulted in enhanced endogenous levels of melatonin accompanied by a reduction in lipid peroxidation under drought stress [101]. Similarly, overexpression of another melatonin biosynthetic gene MzASMT (cloned from Malus zumi) in Arabidopsis plants grown under water deficit conditions, resulted in enhanced scavenging and better drought tolerance [102]. The impact of melatonin on various oxidative stress markers has been summarized in Table 2 . 
Table 2. Summary table explaining the effect of exogenous applied melatonin on various oxidative stress markers under drought stress.

\begin{tabular}{|c|c|c|c|}
\hline Plant Name & Conc. & Impact on Oxidative Stress Markers under Drought Stress & Reference \\
\hline Actinidia chinesis & $100 \mu \mathrm{M}$ & Reduction in MDA content and membrane injury index. & [31] \\
\hline Agrostis stolonifera & $20 \mu \mathrm{M}$ & $\begin{array}{l}\text { Reduction in contents of } \mathrm{H}_{2} \mathrm{O}_{2} \text { and MDA accompanied by declined } \\
\text { electrolyte leakage. }\end{array}$ & [11] \\
\hline Avena nuda & $100 \mu \mathrm{M}$ & Reduction in contents of superoxide anion and $\mathrm{H}_{2} \mathrm{O}_{2}$. & [99] \\
\hline Brassica napus & $50 \mu \mathrm{M}$ & Reduction in $\mathrm{H}_{2} \mathrm{O}_{2}$ content. & [103] \\
\hline Coffea arabica & $300 \mu \mathrm{M}$ & Reduction in lipid peroxidation. & [29] \\
\hline Cucumis sativus & $100 \mu \mathrm{M}$ & $\begin{array}{l}\text { Reduction in contents of } \mathrm{H}_{2} \mathrm{O}_{2} \text {, hydroxyl radical and MDA accompanied } \\
\text { by declined electrolyte leakage. }\end{array}$ & [70] \\
\hline $\begin{array}{l}\text { Dracocephalum } \\
\text { moldavica }\end{array}$ & $100 \mu \mathrm{M}$ & $\begin{array}{l}\text { Reduction in contents of } \mathrm{H}_{2} \mathrm{O}_{2}, \mathrm{MDA} \text { and other aldehydes which cause } \\
\text { oxidative stress accompanied by declined electrolyte leakage. }\end{array}$ & [2] \\
\hline \multirow{2}{*}{ Malus domestica } & \multirow{2}{*}{$100 \mu \mathrm{M}$} & Reduction in electrolyte leakage accompanied by declined $\mathrm{H}_{2} \mathrm{O}_{2}$ content. & [51] \\
\hline & & Reduction in $\mathrm{H}_{2} \mathrm{O}_{2}$ content. & [32] \\
\hline $\begin{array}{l}\text { Malus prunifolia } \\
\text { and } \\
\text { M. hupehensis }\end{array}$ & $100 \mu \mathrm{M}$ & $\begin{array}{l}\text { Reduction in } \mathrm{H}_{2} \mathrm{O}_{2} \text { content. } \\
\text { Accumulation of } \mathrm{ABA} \text { is reduced. }\end{array}$ & [96] \\
\hline \multirow{2}{*}{ Solanum lycopersicum } & $200 \mu \mathrm{M}$ & Reduction in lipid peroxidation. & [88] \\
\hline & $0.1 \mathrm{mM}$ & Reduction in contents of superoxide anion and MDA. & [98] \\
\hline Triticum aestivum & $100 \mu \mathrm{M}$ & $\begin{array}{l}\text { Reduction in contents of superoxide anion, } \mathrm{H}_{2} \mathrm{O}_{2} \text { and MDA accompanied } \\
\text { by declined electrolyte leakage. }\end{array}$ & [30] \\
\hline Vitis vinifera & $100 \mathrm{nM}$ & Reduction in contents of superoxide anion and $\mathrm{H}_{2} \mathrm{O}_{2}$. & [6] \\
\hline Zea mays & $100 \mu \mathrm{M}$ & $\begin{array}{l}\text { Reduction in contents of } \mathrm{H}_{2} \mathrm{O}_{2} \text { and MDA. } \\
\text { Better DPPH scavenging activity. }\end{array}$ & [42] \\
\hline
\end{tabular}

\subsubsection{Impact on Enzymatic and Non-Enzymatic Anti-oxidative Defense System}

Due to drought stress, generation of ROS takes place in plant cells. To regulate the level of ROS, plant's internal defense system (enzymatic and non-enzymatic) gets stimulated. Furthermore, melatonin also triggers this defense system and enhances the scavenging harmful ROS, leading to a reduction in drought induced oxidative stress [27,31]. Melatonin is considered as a multifunctional antioxidant and is a receptor-less scavenger of harmful free radicals [62]. Moreover, melatonin also acts as a stimulator of the enzymatic anti-oxidative defense system, resulting in protection of plants against oxidative damages $[42,104]$.

In drought stressed plants, melatonin promotes activities of ABA degrading enzymes along with $\mathrm{H}_{2} \mathrm{O}_{2}$ scavenging enzymes like CAT, POD and APX [96]. This enhanced activity of above mentioned enzymes results in the decline of $\mathrm{H}_{2} \mathrm{O}_{2}$ in guard cells, indicating a direct involvement of melatonin in scavenging of $\mathrm{H}_{2} \mathrm{O}_{2}[96,105,106]$. In drought stressed plants, melatonin also enhances the activities of other enzymatic anti-oxidative enzymes, such as SOD, GPX, GR, DHAR and MDHAR [27,29,32].

Melatonin mediated ROS scavenging is controlled in drought stressed plants via the regulation of the key enzymatic cycle known as the Asada-Halliwell pathway [98]. Additionally, melatonin also regulates the AsA-GSH cycle which plays an important role in ROS detoxification. This cycle is regulated by enzymes, such as APX, MDHAR, DHAR and GR [30,32]. In chloroplast, GR is responsible for AsA homeostasis [107], and in drought stressed plants, melatonin up-regulates the GR activity [30]. Another enzymatic antioxidant, GPX, has capability to scavenge hydroperoxides, $\mathrm{H}_{2} \mathrm{O}_{2}$ and lipid peroxides, and under drought conditions, melatonin up-regulates the activity of GPX, resulting in efficient ROS scavenging $[30,108]$. Figure 2 explains the melatonin regulated enzymatic anti-oxidative defense system in plants growing under drought stress. 


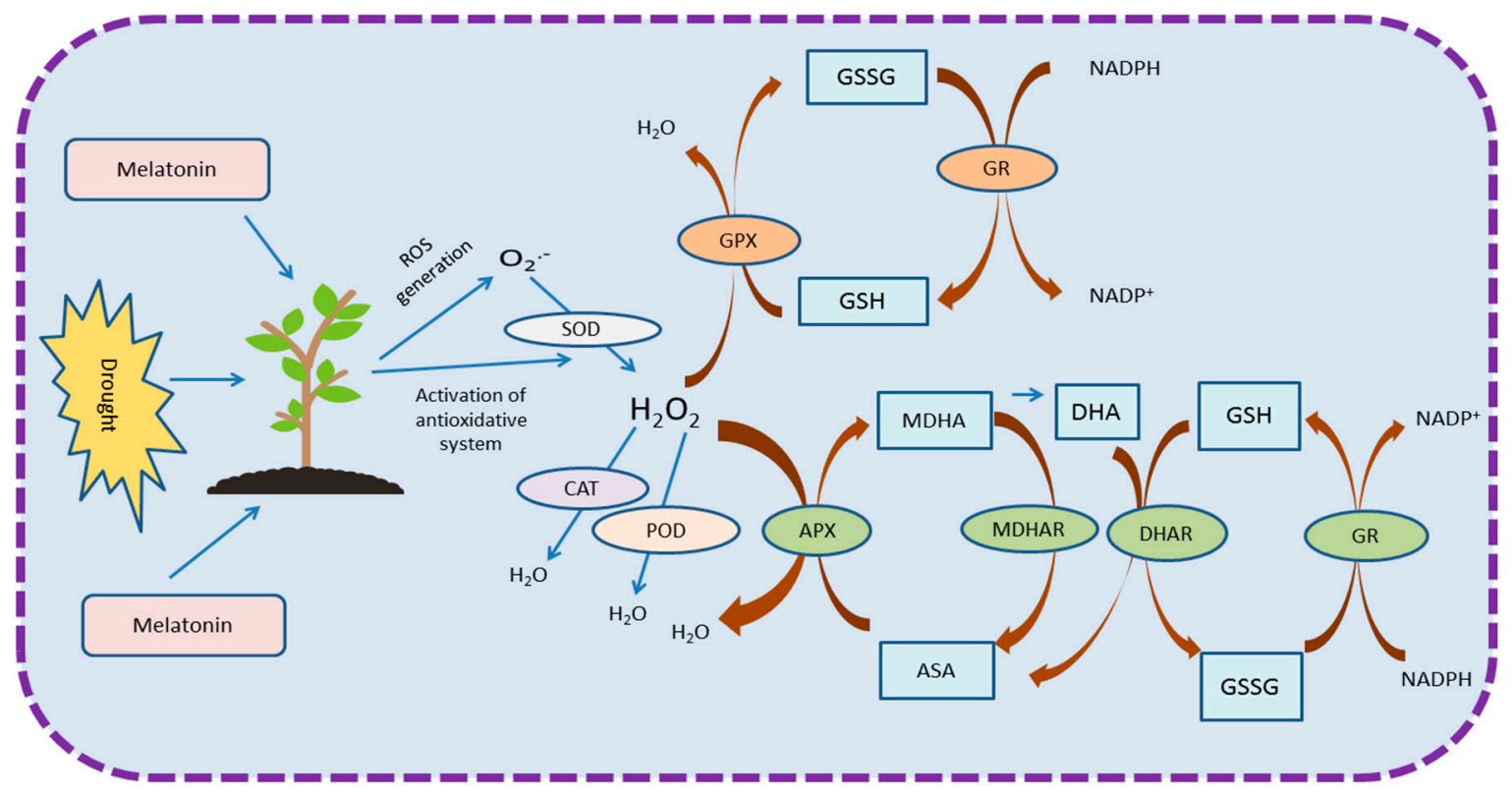

Figure 2. Diagrammatic explanation of the melatonin regulated anti-oxidative system and scavenging of reactive oxygen species. This diagram is a conclusion of various studies mentioned in Table 3. Abbreviations - ASA, ascorbate; APX, ascorbate peroxidase; CAT, catalase; DHA, dehydroascorbate; DHAR, dehydroascorbate reductase; GPX, glutathione peroxidase; GSH, glutathione; GSSG, oxidative glutathione; $\mathrm{GR}$, glutathione reductase; $\mathrm{H}_{2} \mathrm{O}_{2}$, hydrogen peroxide; $\mathrm{MDHA}$, monodehydroascorbate; MDHAR, monodehydroascorbate reductase; NADPH, reduced nicotinamide adenine dinucleotide phosphate; NADP, nicotinamide adenine dinucleotide phosphate; $\mathrm{O}_{2}{ }^{-}{ }^{-}$, superoxide anion; POD, peroxidase; SOD, superoxide dismutase.

Table 3 summarizes the effects of exogenous applied melatonin on the enzymatic antioxidants in plants growing under water deficit conditions.

Table 3. Summary table explaining the effect of exogenous applied melatonin on various anti-oxidative enzymes under drought stress.

\begin{tabular}{|c|c|c|c|}
\hline Plant Name & Conc. & Impact on Antioxidative Enzymes under Drought Stress & Reference \\
\hline Avena nuda & $100 \mu \mathrm{M}$ & Enhanced activities of APX, CAT, POD and SOD. & [99] \\
\hline Brassica napus & $50 \mu \mathrm{M}$ & Enhanced activities of APX, CAT and POD. & [103] \\
\hline Coffea arabica & $300 \mu \mathrm{M}$ & $\begin{array}{l}\text { Enhanced activities of APX and CAT, but no significant difference } \\
\text { in SOD activity. }\end{array}$ & [29] \\
\hline Cucumis sativus & $100 \mu \mathrm{M}$ & Enhanced activities of CAT, POD and SOD. & [70] \\
\hline Dracocephalum moldavica & $100 \mu \mathrm{M}$ & Enhanced activities of APX, CAT, GPX and SOD. & [27] \\
\hline Malus domestica & $100 \mu \mathrm{M}$ & Enhanced activities of APX, CAT, POD, DHAR, MDHAR and GR. & [32] \\
\hline $\begin{array}{l}\text { Malus prunifolia } \\
\text { and } \\
\text { M. hupehensis }\end{array}$ & $100 \mu \mathrm{M}$ & Enhanced activities of APX, CAT and POD. & [96] \\
\hline \multirow{2}{*}{ Solanum lycopersicum } & $200 \mu \mathrm{M}$ & Enhanced GR activity. & [88] \\
\hline & $0.1 \mathrm{mM}$ & Enhanced activities of APX, CAT, GR, POD and SOD. & [98] \\
\hline Triticum aestivum & $100 \mu \mathrm{M}$ & $\begin{array}{c}\text { Enhanced activities of APX, GPX, DHAR, MDHAR, GST and GR. } \\
\text { Up-regulation in the transcript levels of APX, DHAR, MDHAR4, } \\
\text { GPX, GPX1, GR and GST2. }\end{array}$ & [30] \\
\hline Vitis vinifera & $100 \mathrm{nM}$ & Enhanced activities of CAT, POD and SOD. & [6] \\
\hline Zea mays & $100 \mu \mathrm{M}$ & Enhanced activities of APX, CAT, POD and SOD. & [42] \\
\hline
\end{tabular}

APX, ascorbate peroxidase; CAT, catalase; DHAR, dehydroascorbate reductase; GPX, glutathione peroxidase; GR, glutathione reductase; GST, glutathione-S-transferase; MDHAR, monodehydroascorbate reductase; POD, peroxidase; SOD, superoxide dismutase. 
The regulation of AsA-GSH cycle by melatonin under drought stress results in the enhancement of AsA/DHA and GSH/GSSG ratios [32,98]. The enhanced activity of GR is responsible for the increased ratio of $\mathrm{NADP}^{+} / \mathrm{NADPH}$ followed by better performance of photosynthetic electron transport (PET). This increased PET also inhibits the generation of superoxide anions [98]. Moreover, melatonin mediated control of superoxide anion production under drought stress is also due to the fact that melatonin reduces the consumption of $\mathrm{O}_{2}$ flux in those conditions when ADP levels are higher [98]. Moreover, melatonin also enhances the DPPH-radical scavenging efficiency of plants growing under water deficit conditions [42]. After melatonin treatment, an increase in AsA and GSH contents in drought stressed plants is also accompanied by a reduced $\mathrm{H}_{2} \mathrm{O}_{2}$ content [98]. This stimulated biosynthesis of AsA and GSH is considered to be necessary for the ROS balance in plants under low water conditions [30]. It is also suggested that glutamylcysteine synthase, which is a key enzyme of GSH biosynthetic pathway [109], might have up-regulated by melatonin, but further research is required to study the exact mechanism. Additionally, AsA and GSH are also involved in the scavenging of superoxide anions, and the process is further triggered by melatonin under drought stress [6]. Proline is a non-enzymatic antioxidant which is also involved in providing resistance to plants under water deficit conditions and melatonin treatment enhances its biosynthesis, resulting in the reduction of drought induced oxidative stress [6]. Moreover, it is also suggested that proline aids in maintaining cell function by reducing the levels of ROS and stabilizing cell membranes [6]. Phenolic compounds are also a potential antioxidant and their accumulation is boosted by exogenous applied melatonin, which can be beneficial for plants growing under drought stress [89]. Melatonin also stimulates the biosynthesis of compatible solutes, such as soluble sugars, which are responsible for maintaining the turgor and osmotic pressure of plant cells growing in water deficit conditions [29]. This stimulated biosynthesis of osmolytes is a part of a mechanism for maintaining the osmotic balance of plants under drought stress $[41,110]$. Additionally, they also play a role in enhancing the ROS scavenging efficiency and cell wall protection against abiotic stress conditions [111,112]. The various effects of melatonin on non-enzymatic antioxidants under drought stress have been summarized in Table 4.

Table 4. Summary table explaining the effect of exogenous applied melatonin on various non-enzymatic antioxidants and osmotic adjustments under drought stress.

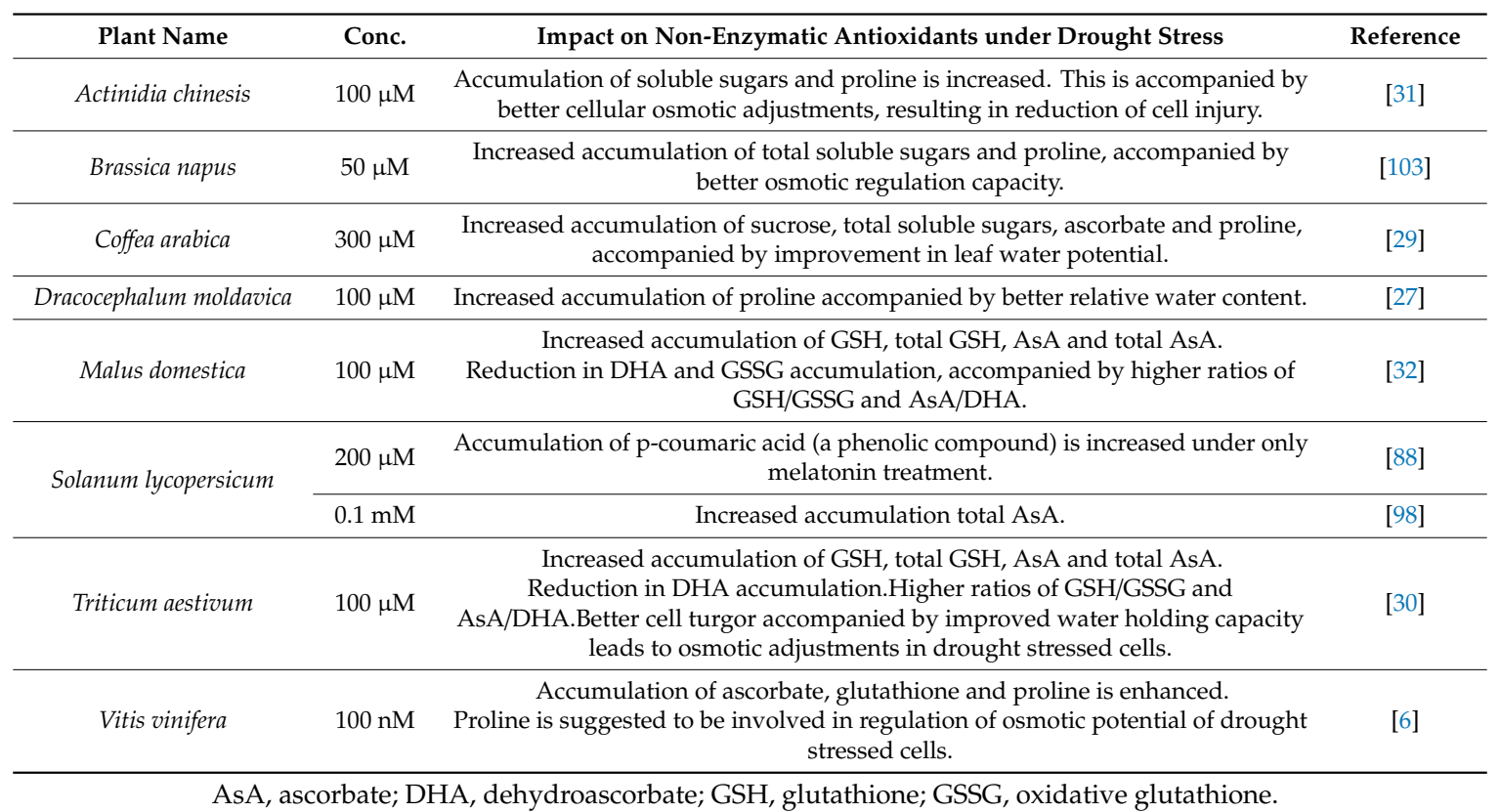

AsA, ascorbate; DHA, dehydroascorbate; GSH, glutathione; GSSG, oxidative glutathione. 


\subsection{Regulation of Other Biological Processes Related to Drought Tolerance}

Mitogen-activated protein kinase (MAPK) cascade pathways play a crucial role in the regulation of the plant's biological processes under abiotic stresses, including drought [113]. Transcription factors (TFs), such as NAC, WRKY, MYB and DREB are the main components of MAPK signaling pathway in plants under stress conditions [114]. These TFs are involved in the regulation of various stress responsive genes responsible for abiotic stress tolerance [115]. Melatonin under drought stress regulates the MAPK pathway by up-regulating the expression pattern of MAPKs, such as Asmap1 and Aspk11. It is accompanied by the up-regulation of key TFs, including WRKY1, DREB2 and MYB [99]. This melatonin-mediated regulation of MAPK cascade is believed to be regulated via $\mathrm{H}_{2} \mathrm{O}_{2}$ signaling, resulting in the enhanced plant's resistance against drought stress [99]. Drought stress in plants causes negative impacts upon the nitrogen metabolism $[116,117]$. Melatonin regulates nitrogen metabolism under drought stress by modulating the physiological and molecular aspects of plant biology [51]. The activities of nitrogen metabolic enzymes, such as NR, NiR, GS and GOGAT are enhanced by melatonin [51]. Furthermore, the reason behind melatonin induced activities of nitrogen metabolic enzymes is explained by the fact that melatonin also up-regulates the expression pattern of genes, including NR, NiR, GS and GOGAT in plants under water deficit conditions [51]. Additionally, transcript levels of genes involved in nitrogen uptake, AMT (ammonium transporter) and NRT (nitrate transporter) are also enhanced by melatonin in plants growing under drought stress [51]. Drought induced senescence is delayed after melatonin application, which is due to the down-regulation of gene SAG12 (senescence associated gene 12) [32]. Furthermore, this delaying of senescence is favored by melatonin mediated overexpression of genes, such as JUB1 and DREB2A under drought conditions [11].

Transgenic studies involving overexpression of TaCOMT in Arabidopsis revealed that melatonin up-regulated various drought responsive genes, such as RAB18, RD29A, KIN1 and DREB2A [101]. Additionally, it is also suggested that melatonin provides drought tolerance by regulating GA and IAA biosynthetic pathways. Melatonin is believed to suppress IAA biosynthesis via GA-signaling accompanied by better drought resistance in plants [101]. Cytokinin (CK) biosynthesis is stimulated by melatonin by up-regulating the transcript levels of key genes involved in CK-signaling, including Type-A RRs, Type-B RRs (response regulators), HKs (histidine kinases) and HPs (histidine phosphotransferases) [11]. This melatonin mediated CK-signaling has been associated with the induction of drought resistance in plants [11].

Cuticle waxes are important for plants growing under low water conditions, as these compounds assist in controlling the water loss through the leaf's surface [97]. Melatonin stimulates the biosynthesis of cuticular waxes and increases their deposition on the leaf's surface, resulting in minimum water loss. This enhanced biosynthesis is due to the up-regulation of the transcript levels of genes, such as KCS1 (ketoacyl-CoA synthase 1), CER3 (ECERIFERUM3), TTS1 (triterpenoid synthase 1) and LTP1 (lipid transfer protein 1), which encodes enzymes involved in wax biosynthetic pathways [97].

\section{Conclusions}

Melatonin provides resistance to plants growing under drought conditions by enhancing the scavenging of ROS. This prevents cells from oxidative damage and assists in the recovery of chloroplast structures resulting in the improvement of photosynthetic efficiency of plants. Melatonin mediated protection of drought stressed cells is regulated via stimulated cell signaling which ultimately controls various physiological aspects at a molecular level. Figure 3 provides a detailed overview of melatonin mediated regulation of plant biology under drought stress. As drought stress directly reduces the yield and quality of crops, the implication of melatonin at a field level can be helpful from an agronomic point of view. Some recent studies have also reported the enhanced drought tolerance after gene manipulation (GM) and developing genetic modified plants with better melatonin biosynthesis. This GM technology can be beneficial in developing better drought resistant varieties. Moreover, the identification of other key genes involved in providing drought resistance and studying their behavior under melatonin treatment can open new possibilities to develop drought tolerant crops. 


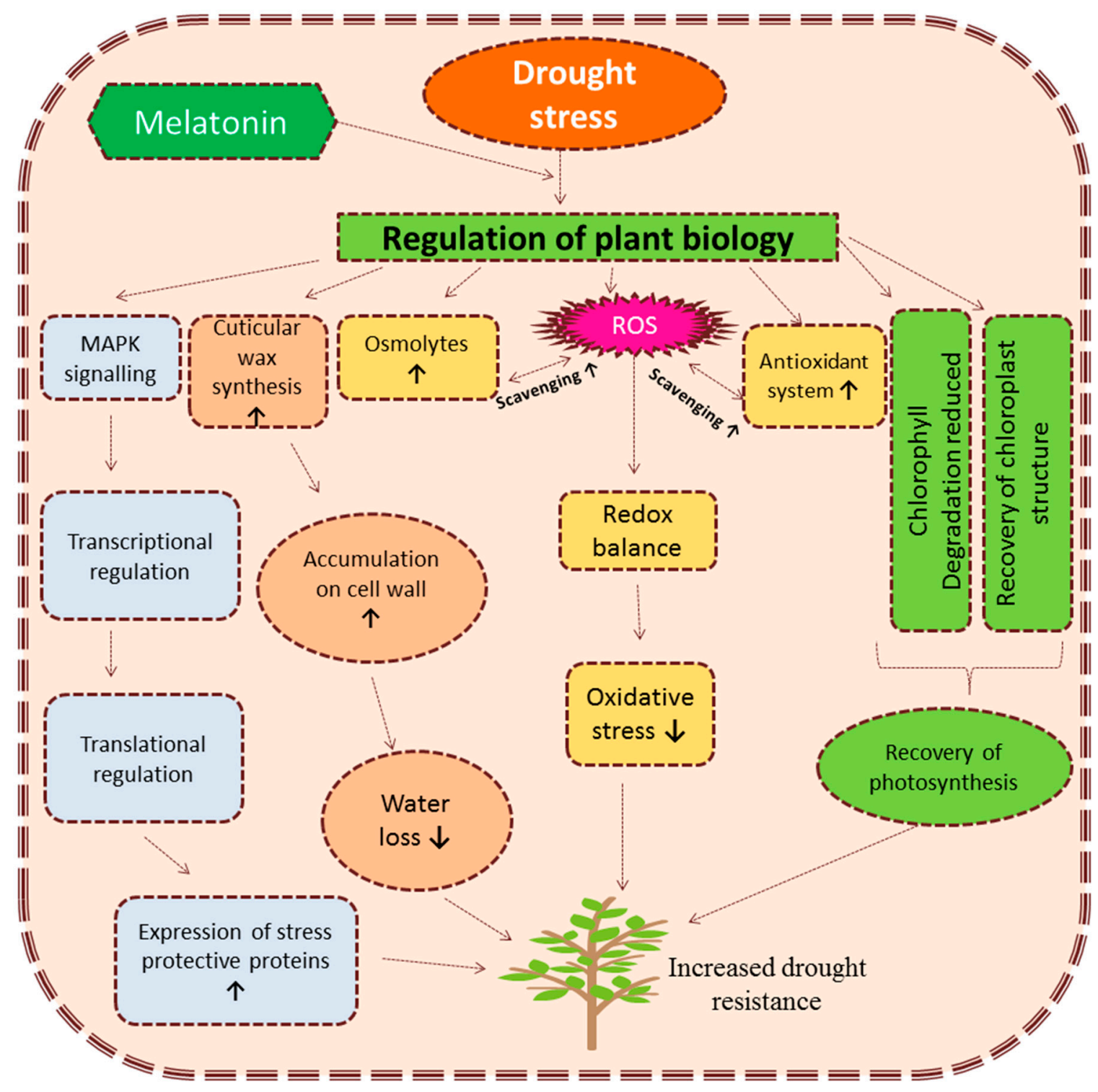

Figure 3. An overview of melatonin mediated regulation of drought stress in plants. ROS (reactive oxygen species), MAPK (Mitogen-activated protein kinase) $\uparrow=$ increase, $\downarrow$ decrease.

Author Contributions: A.S. and B.Z. drafted the outline of review. A.S. wrote the initial draft and B.Z. participated in revision of initial draft.

Funding: We acknowledge the different funding agencies: This study was supported by National Key Research and Development Program of China (2018YFD1000600); Independent research topics of the State Key Laboratory of Subtropical Silviculture (ZY20180208, ZY20180308); Key Research and Development Program of Zhejiang Province (2018C02004); Key Project of Zhejiang Provincial Natural Science Foundation (LZ18C160001); Fruit Innovation Team Project of Zhejiang Province (2016C02052-12); National Undergraduate Innovation and Entrepreneurship Training Project (201610341010); Undergraduate Science and Technology Innovation Plan of Zhejiang Province (2017R412006); Undergraduate Research Training Program in Zhejiang A \& F University (102-2013200005, 102-2013200041, 102-2013200042,KX20180047, KX20180043, KX20180065).

Conflicts of Interest: The authors declare no conflicts of interest. 


\section{References}

1. Reddy, A.R.; Chaitanya, K.V.; Vivekanandan, M. Drought-induced responses of photosynthesis and antioxidant metabolism in higher plants. J. Plant Physiol. 2004, 161, 1189-1202. [CrossRef]

2. Tanveer, M.; Shahzad, B.; Sharma, A.; Khan, E.A. 24-Epibrassinolide application in plants: An implication for improving drought stress tolerance in plants. Plant Physiol. Biochem. 2019, 135, 295-303. [CrossRef] [PubMed]

3. Fahad, S.; Bajwa, A.A.; Nazir, U.; Anjum, S.A.; Farooq, A.; Zohaib, A.; Sadia, S.; Nasim, W.; Adkins, S.; Saud, S.; et al. Crop Production under Drought and Heat Stress: Plant Responses and Management Options. Front. Plant Sci. 2017, 8, 1147. [CrossRef] [PubMed]

4. Okçu, G.; Kaya, M.D.; Atak, M. Effects of salt and drought stresses on germination and seedling growth of pea (Pisum sativum L.). Turk. J. Agric. For. 2005, 29, 237-242.

5. Cruz de Carvalho, M.H. Drought stress and reactive oxygen species: Production, scavenging and signaling. Plant Signal. Behav. 2008, 3, 156-165. [CrossRef]

6. $\quad$ Meng, J.F.; Xu, T.F.; Wang, Z.Z.; Fang, Y.L.; Xi, Z.M.; Zhang, Z.W. The ameliorative effects of exogenous melatonin on grape cuttings under water-deficient stress: Antioxidant metabolites, leaf anatomy, and chloroplast morphology. J. Pineal Res. 2014, 57, 200-212. [CrossRef] [PubMed]

7. Shao, R.X.; Xin, L.F.; Zheng, H.F.; Li, L.L.; Ran, W.L.; Mao, J.; Yang, Q.H. Changes in chloroplast ultrastructure in leaves of drought-stressed maize inbred lines. Photosynthetica 2016, 54, 74-80. [CrossRef]

8. Chen, X.; Qiu, L.; Guo, H.; Wang, Y.; Yuan, H.; Yan, D.; Zheng, B. Spermidine induces physiological and biochemical changes in southern highbush blueberry under drought stress. Braz. J. Bot. 2017, 40, 841-851. [CrossRef]

9. Ying, Y.; Yue, Y.; Huang, X.; Wang, H.; Mei, L.; Yu, W.; Zheng, B.; Wu, J. Salicylic acid induces physiological and biochemical changes in three Red bayberry (Myric rubra) genotypes under water stress. Plant Growth Regul. 2013, 71, 181-189. [CrossRef]

10. Cao, B.-L.; Ma, Q.; Zhao, Q.; Wang, L.; Xu, K. Effects of silicon on absorbed light allocation, antioxidant enzymes and ultrastructure of chloroplasts in tomato leaves under simulated drought stress. Sci. Hortic. 2015, 194, 53-62. [CrossRef]

11. Ma, X.; Zhang, J.; Burgess, P.; Rossi, S.; Huang, B. Interactive effects of melatonin and cytokinin on alleviating drought-induced leaf senescence in creeping bentgrass (Agrostis stolonifera). Environ. Exp. Bot. 2018, 145, 1-11. [CrossRef]

12. Gill, S.S.; Tuteja, N. Reactive oxygen species and antioxidant machinery in abiotic stress tolerance in crop plants. Plant Physiol. Biochem. 2010, 48, 909-930. [CrossRef] [PubMed]

13. Talaat, N.B.; Shawky, B.T.; Ibrahim, A.S. Alleviation of drought-induced oxidative stress in maize (Zea mays L.) plants by dual application of 24-epibrassinolide and spermine. Environ. Exp. Bot. 2015, 113, 47-58. [CrossRef]

14. Murshed, R.; Lopez-Lauri, F.; Sallanon, H. Effect of water stress on antioxidant systems and oxidative parameters in fruits of tomato (Solanum lycopersicon L, cv. Micro-tom). Physiol. Mol. Biol. Plants 2013, 19, 363-378. [CrossRef] [PubMed]

15. Noctor, G.; Mhamdi, A.; Foyer, C.H. The roles of reactive oxygen metabolism in drought: Not so cut and dried. Plant Physiol. 2014, 164, 1636-1648. [CrossRef] [PubMed]

16. Bari, R.; Jones, J.D. Role of plant hormones in plant defence responses. Plant Mol. Biol. 2009, 69, 473-488. [CrossRef] [PubMed]

17. Kachroo, A.; Kachroo, P. Salicylic acid-, jasmonic acid- and ethylene-mediated regulation of plant defense signaling. Genet. Eng. 2007, 28, 55-83.

18. Fan, J.; Xie, Y.; Zhang, Z.; Chen, L. Melatonin: A Multifunctional Factor in Plants. Int. J. Mol. Sci. 2018, 19, 1528. [CrossRef]

19. Guo, H.; Feng, X.; Hong, C.; Chen, H.; Zeng, F.; Zheng, B.; Jiang, D. Malate secretion from the root system is an important reason for higher resistance of Miscanthus sacchariflorus to cadmium. Physiol. Plant. 2017, 159, 340-353. [CrossRef]

20. Tanveer, M.; Shahzad, B.; Sharma, A.; Biju, S.; Bhardwaj, R. 24-Epibrassinolide; an active brassinolide and its role in salt stress tolerance in plants: A review. Plant Physiol. Biochem. 2018, 130, 69-79. [CrossRef] 
21. Sharma, A.; Kumar, V.; Kumar, R.; Shahzad, B.; Thukral, A.K.; Bhardwaj, R. Brassinosteroid-mediated pesticide detoxification in plants: A mini-review. Cogent Food Agric. 2018, 4, 1436212. [CrossRef]

22. Khan, T.A.; Yusuf, M.; Ahmad, A.; Bashir, Z.; Saeed, T.; Fariduddin, Q.; Hayat, S.; Mock, H.P.; Wu, T. Proteomic and physiological assessment of stress sensitive and tolerant variety of tomato treated with brassinosteroids and hydrogen peroxide under low-temperature stress. Food Chem. 2019, 289, 500-511. [CrossRef] [PubMed]

23. Shahzad, B.; Tanveer, M.; Che, Z.; Rehman, A.; Cheema, S.A.; Sharma, A.; Song, H.; Rehman, S.U.; Zhaorong, D. Role of 24-epibrassinolide (EBL) in mediating heavy metal and pesticide induced oxidative stress in plants: A review. Ecotoxicol. Environ. Saf. 2018, 147, 935-944. [CrossRef] [PubMed]

24. Kohli, S.K.; Handa, N.; Sharma, A.; Kumar, V.; Kaur, P.; Bhardwaj, R. Synergistic effect of 24-epibrassinolide and salicylic acid on photosynthetic efficiency and gene expression in Brassica juncea L. under Pb stress. Turk. J. Biol. 2017, 41, 943-953. [CrossRef]

25. Sharma, A.; Thakur, S.; Kumar, V.; Kesavan, A.K.; Thukral, A.K.; Bhardwaj, R. 24-epibrassinolide stimulates imidacloprid detoxification by modulating the gene expression of Brassica juncea L. BMC Plant Biol. 2017, 17, 56. [CrossRef] [PubMed]

26. Guo, H.; Chen, H.; Hong, C.; Jiang, D.; Zheng, B. Exogenous malic acid alleviates cadmium toxicity in Miscanthus sacchariflorus through enhancing photosynthetic capacity and restraining ROS accumulation. Ecotoxicol. Environ. Saf. 2017, 141, 119-128. [CrossRef] [PubMed]

27. Kabiri, R.; Hatami, A.; Oloumi, H.; Naghizadeh, M.; Nasibi, F.; Tahmasebi, Z. Foliar application of melatonin induces tolerance to drought stress in Moldavian balm plants (Dracocephalum moldavica) through regulating the antioxidant system. Folia Hortic. 2018, 30, 155-167. [CrossRef]

28. Zhao, D.; Yu, Y.; Shen, Y.; Liu, Q.; Zhao, Z.; Sharma, R.; Reiter, R.J. Melatonin Synthesis and Function: Evolutionary History in Animals and Plants. Front. Endocrinol. 2019, 10, 249. [CrossRef]

29. Campos, C.N.; Ávila, R.G.; de Souza, K.R.D.; Azevedo, L.M.; Alves, J.D. Melatonin reduces oxidative stress and promotes drought tolerance in young Coffea arabica L. plants. Agric. Water Manag. 2019, 211, 37-47. [CrossRef]

30. Cui, G.; Zhao, X.; Liu, S.; Sun, F.; Zhang, C.; Xi, Y. Beneficial effects of melatonin in overcoming drought stress in wheat seedlings. Plant Physiol. Biochem. 2017, 118, 138-149. [CrossRef]

31. Liang, D.; Ni, Z.; Xia, H.; Xie, Y.; Lv, X.; Wang, J.; Lin, L.; Deng, Q.; Luo, X. Exogenous melatonin promotes biomass accumulation and photosynthesis of kiwifruit seedlings under drought stress. Sci. Hortic. 2019, 246, 34-43. [CrossRef]

32. Wang, P.; Sun, X.; Li, C.; Wei, Z.; Liang, D.; Ma, F. Long-term exogenous application of melatonin delays drought-induced leaf senescence in apple. J. Pineal Res. 2013, 54, 292-302. [CrossRef]

33. Martinez, V.; Nieves-Cordones, M.; Lopez-Delacalle, M.; Rodenas, R.; Mestre, T.C.; Garcia-Sanchez, F.; Rubio, F.; Nortes, P.A.; Mittler, R.; Rivero, R.M. Tolerance to Stress Combination in Tomato Plants: New Insights in the Protective Role of Melatonin. Molecules 2018, 23, 535. [CrossRef]

34. Arnao, M.B.; Hernandez-Ruiz, J. Melatonin: A New Plant Hormone and/or a Plant Master Regulator? Trends Plant Sci. 2019, 24, 38-48. [CrossRef] [PubMed]

35. Zhang, N.; Sun, Q.; Zhang, H.; Cao, Y.; Weeda, S.; Ren, S.; Guo, Y.D. Roles of melatonin in abiotic stress resistance in plants. J. Exp. Bot. 2015, 66, 647-656. [CrossRef] [PubMed]

36. Hussain, H.A.; Hussain, S.; Khaliq, A.; Ashraf, U.; Anjum, S.A.; Men, S.; Wang, L. Chilling and Drought Stresses in Crop Plants: Implications, cross Talk, and Potential Management Opportunities. Front. Plant Sci. 2018, 9, 393. [CrossRef]

37. Ahmad, Z.; Anjum, S.; Waraich, E.A.; Ayub, M.A.; Ahmad, T.; Tariq, R.M.S.; Ahmad, R.; Iqbal, M.A. Growth, physiology, and biochemical activities of plant responses with foliar potassium application under drought stress-A review. J. Plant Nutr. 2018, 41, 1734-1743. [CrossRef]

38. Foyer, C.; Noctor, G. Oxygen processing in photosynthesis: Regulation and signaling. New Phytol. 2000, 146, 359-388. [CrossRef]

39. Bota, J.; Medrano, H.; Flexas, J. Is photosynthesis limited by decreased Rubisco activity and RuBP content under progressive water stress? New Phytol. 2004, 162, 671-681. [CrossRef]

40. Fu, J.; Huang, B. Involvement of antioxidants and lipid peroxidation in the adaptation of two cool-season grasses to localized drought stress. Environ. Exp. Bot. 2001, 45, 105-114. [CrossRef] 
41. Basu, S.; Ramegowda, V.; Kumar, A.; Pereira, A. Plant adaptation to drought stress. F1000Research 2016, 5, 1554. [CrossRef] [PubMed]

42. Ye, J.; Wang, S.; Deng, X.; Yin, L.; Xiong, B.; Wang, X. Melatonin increased maize (Zea mays L.) seedling drought tolerance by alleviating drought-induced photosynthetic inhibition and oxidative damage. Acta Physiol. Plant. 2016, 38, 48. [CrossRef]

43. Osakabe, Y.; Osakabe, K.; Shinozaki, K.; Tran, L.-S.P. Response of plants to water stress. Front. Plant Sci. 2014, 5, 86. [CrossRef] [PubMed]

44. Behnam, B.; Iuchi, S.; Fujita, M.; Fujita, Y.; Takasaki, H.; Osakabe, Y.; Yamaguchi-Shinozaki, K.; Kobayashi, M.; Shinozaki, K. Characterization of the promoter region of an Arabidopsis gene for 9-cis-epoxycarotenoid dioxygenase involved in dehydration-inducible transcription. DNA Res. 2013, 20, 315-324. [CrossRef] [PubMed]

45. Bhargava, S.; Sawant, K. Drought stress adaptation: Metabolic adjustment and regulation of gene expression. Plant Breed. 2013, 132, 21-32. [CrossRef]

46. Scippa, G.S.; Di Michele, M.; Onelli, E.; Patrignani, G.; Chiatante, D.; Bray, E.A. The histone-like protein H1-S and the response of tomato leaves to water deficit. J. Exp. Bot. 2004, 55, 99-109. [CrossRef] [PubMed]

47. de Campos, M.K.F.; de Carvalho, K.; de Souza, F.S.; Marur, C.J.; Pereira, L.F.P.; Filho, J.C.B.; Vieira, L.G.E. Drought tolerance and antioxidant enzymatic activity in transgenic 'Swingle' citrumelo plants over-accumulating proline. Environ. Exp. Bot. 2011, 72, 242-250. [CrossRef]

48. Nayyar, H.; Gupta, D. Differential sensitivity of C3 and C4 plants to water deficit stress: Association with oxidative stress and antioxidants. Environ. Exp. Bot. 2006, 58, 106-113. [CrossRef]

49. Liu, F.; Jensen, C.R.; Andersen, M.N. Drought stress effect on carbohydrate concentration in soybean leaves and pods during early reproductive development: Its implication in altering pod set. Field Crops Res. 2004, 86, 1-13. [CrossRef]

50. Gunes, A.; Inal, A.; Adak, M.S.; Bagci, E.G.; Cicek, N.; Eraslan, F. Effect of drought stress implemented at preor post-anthesis stage on some physiological parameters as screening criteria in chickpea cultivars. Russ. J. Plant Physiol. 2007, 55, 59-67. [CrossRef]

51. Liang, B.; Ma, C.; Zhang, Z.; Wei, Z.; Gao, T.; Zhao, Q.; Ma, F.; Li, C. Long-term exogenous application of melatonin improves nutrient uptake fluxes in apple plants under moderate drought stress. Environ. Exp. Bot. 2018, 155, 650-661. [CrossRef]

52. Hu, Y.; Schmidhalter, U. Drought and salinity: A comparison of their effects on mineral nutrition of plants. J. Plant Nutr. Soil Sci. 2005, 168, 541-549. [CrossRef]

53. Kuchenbuch, R.; Claassen, N.; Jungk, A. Potassium availability in relation to soil moisture. Plant Soil 1986, 95, 221-231. [CrossRef]

54. Mittler, R. Oxidative stress, antioxidants and stress tolerance. Trends Plant Sci. 2002, 7, 405-410. [CrossRef]

55. Apel, K.; Hirt, H. Reactive oxygen species: Metabolism, oxidative stress, and signal transduction. Annu. Rev. Plant Biol. 2004, 55, 373-399. [CrossRef] [PubMed]

56. Cruz, R.P.D.; Milach, S.C.K. Cold tolerance at the germination stage of rice: Methods of evaluation and characterization of genotypes. Sci. Agric. 2004, 61,1-8. [CrossRef]

57. Sharma, P.; Dubey, R.S. Drought Induces Oxidative Stress and Enhances the Activities of Antioxidant Enzymes in Growing Rice Seedlings. Plant Growth Regul. 2005, 46, 209-221. [CrossRef]

58. Subbarao, G.V.; Nam, N.H.; Chauhan, Y.S.; Johansen, C. Osmotic adjustment, water relations and carbohydrate remobilization in pigeonpea under water deficits. J. Plant Physiol. 2000, 157, 651-659. [CrossRef]

59. Farooq, M.; Aziz, T.; Wahid, A.; Lee, D.-J.; Siddique, K.H.J.C.; Science, P. Chilling tolerance in maize: Agronomic and physiological approaches. Crop Pasture Sci. 2009, 60, 501-516. [CrossRef]

60. Kiani, S.P.; Talia, P.; Maury, P.; Grieu, P.; Heinz, R.; Perrault, A.; Nishinakamasu, V.; Hopp, E.; Gentzbittel, L.; Paniego, N.; et al. Genetic analysis of plant water status and osmotic adjustment in recombinant inbred lines of sunflower under two water treatments. Plant Sci. 2007, 172, 773-787. [CrossRef]

61. Chimenti, C.A.; Marcantonio, M.; Hall, A.J. Divergent selection for osmotic adjustment results in improved drought tolerance in maize (Zea mays L.) in both early growth and flowering phases. Field Crops Res. 2006, 95, 305-315. [CrossRef]

62. Arnao, M.B.; Hernandez-Ruiz, J. Melatonin: Plant growth regulator and/or biostimulator during stress? Trends Plant Sci. 2014, 19, 789-797. [CrossRef] [PubMed] 
63. Kanwar, M.K.; Yu, J.; Zhou, J. Phytomelatonin: Recent advances and future prospects. J. Pineal Res. 2018, 65, e12526. [CrossRef] [PubMed]

64. Hernandez-Ruiz, J.; Cano, A.; Arnao, M.B. Melatonin: A growth-stimulating compound present in lupin tissues. Planta 2004, 220, 140-144. [CrossRef] [PubMed]

65. Hernandez-Ruiz, J.; Cano, A.; Arnao, M.B. Melatonin acts as a growth-stimulating compound in some monocot species. J. Pineal Res. 2005, 39, 137-142. [CrossRef]

66. Chen, Q.; Qi, W.B.; Reiter, R.J.; Wei, W.; Wang, B.M. Exogenously applied melatonin stimulates root growth and raises endogenous indoleacetic acid in roots of etiolated seedlings of Brassica juncea. J. Plant Physiol. 2009, 166, 324-328. [CrossRef]

67. Murch, S.J.; Campbell, S.S.B.; Saxena, P.K. The role of serotonin and melatonin in plant morphogenesis: Regulation of auxin-induced root organogenesis in in vitro-cultured explants of Hypericum perforatum $\mathrm{L}$. In Vitro Cell. Dev. Biol. Plant 2001, 37, 786-793. [CrossRef]

68. Murch, S.J.; Saxena, P.K. Melatonin: A potential regulator of plant growth and development? In Vitro Cell. Dev. Biol. Plant 2002, 38, 531-536. [CrossRef]

69. Park, S.; Back, K. Melatonin promotes seminal root elongation and root growth in transgenic rice after germination. J. Pineal Res. 2012, 53, 385-389. [CrossRef]

70. Zhang, N.; Zhao, B.; Zhang, H.J.; Weeda, S.; Yang, C.; Yang, Z.C.; Ren, S.; Guo, Y.D. Melatonin promotes water-stress tolerance, lateral root formation, and seed germination in cucumber (Cucumis sativus L.). J. Pineal Res. 2013, 54, 15-23. [CrossRef]

71. Sarropoulou, V.; Dimassi-Theriou, K.; Therios, I.; Koukourikou-Petridou, M. Melatonin enhances root regeneration, photosynthetic pigments, biomass, total carbohydrates and proline content in the cherry rootstock PHL-C (Prunus avium $\times$ Prunus cerasus). Plant Physiol. Biochem. 2012, 61, 162-168. [CrossRef] [PubMed]

72. Sarrou, E.; Therios, I.; Dimassi-Theriou, K. Melatonin and other factors that promote rooting and sprouting of shoot cuttings in Punica granatum cv. Wonderful. Turk. J. Bot. 2014, 38, 293-301. [CrossRef]

73. Arnao, M.B.; Hernandez-Ruiz, J. Melatonin promotes adventitious- and lateral root regeneration in etiolated hypocotyls of Lupinus albus L. J. Pineal Res. 2007, 42, 147-152. [CrossRef] [PubMed]

74. Zhang, N.; Zhang, H.J.; Zhao, B.; Sun, Q.Q.; Cao, Y.Y.; Li, R.; Wu, X.X.; Weeda, S.; Li, L.; Ren, S.; et al. The RNA-seq approach to discriminate gene expression profiles in response to melatonin on cucumber lateral root formation. J. Pineal Res. 2014, 56, 39-50. [CrossRef] [PubMed]

75. Koyama, F.C.; Carvalho, T.L.; Alves, E.; da Silva, H.B.; de Azevedo, M.F.; Hemerly, A.S.; Garcia, C.R. The structurally related auxin and melatonin tryptophan-derivatives and their roles in Arabidopsis thaliana and in the human malaria parasite Plasmodium falciparum. J. Eukaryot. Microbiol. 2013, 60, 646-651. [CrossRef]

76. Pelagio-Flores, R.; Munoz-Parra, E.; Ortiz-Castro, R.; Lopez-Bucio, J. Melatonin regulates Arabidopsis root system architecture likely acting independently of auxin signaling. J. Pineal Res. 2012, 53, 279-288. [CrossRef] [PubMed]

77. Li, X.; Tan, D.X.; Jiang, D.; Liu, F. Melatonin enhances cold tolerance in drought-primed wild-type and abscisic acid-deficient mutant barley. J. Pineal Res. 2016, 61, 328-339. [CrossRef]

78. Xu, W.; Cai, S.Y.; Zhang, Y.; Wang, Y.; Ahammed, G.J.; Xia, X.J.; Shi, K.; Zhou, Y.H.; Yu, J.Q.; Reiter, R.J.; et al. Melatonin enhances thermotolerance by promoting cellular protein protection in tomato plants. J. Pineal Res. 2016, 61, 457-469. [CrossRef]

79. Zuo, Z.Y.; Sun, L.Y.; Wang, T.Y.; Miao, P.; Zhu, X.C.; Liu, S.Q.; Song, F.B.; Mao, H.P.; Li, X.N. Melatonin Improves the Photosynthetic Carbon Assimilation and Antioxidant Capacity in Wheat Exposed to Nano-ZnO Stress. Molecules 2017, 22, 1727. [CrossRef]

80. Zhao, H.; Su, T.; Huo, L.; Wei, H.; Jiang, Y.; Xu, L.; Ma, F. Unveiling the mechanism of melatonin impacts on maize seedling growth: Sugar metabolism as a case. J. Pineal Res. 2015, 59, 255-266. [CrossRef]

81. Liang, C.; Zheng, G.; Li, W.; Wang, Y.; Hu, B.; Wang, H.; Wu, H.; Qian, Y.; Zhu, X.G.; Tan, D.X.; et al. Melatonin delays leaf senescence and enhances salt stress tolerance in rice. J. Pineal Res. 2015, 59, 91-101. [CrossRef] [PubMed]

82. Wang, P.; Yin, L.; Liang, D.; Li, C.; Ma, F.; Yue, Z. Delayed senescence of apple leaves by exogenous melatonin treatment: Toward regulating the ascorbate-glutathione cycle. J. Pineal Res. 2012, 53, 11-20. [CrossRef] [PubMed] 
83. Posmyk, M.M.; Janas, K.M. Effects of seed hydropriming in presence of exogenous proline on chilling injury limitation in Vigna radiata L. seedlings. Acta Physiol. Plant. 2007, 29, 509-517. [CrossRef]

84. Wei, W.; Li, Q.T.; Chu, Y.N.; Reiter, R.J.; Yu, X.M.; Zhu, D.H.; Zhang, W.K.; Ma, B.; Lin, Q.; Zhang, J.S.; et al. Melatonin enhances plant growth and abiotic stress tolerance in soybean plants. J. Exp. Bot. 2015, 66, 695-707. [CrossRef] [PubMed]

85. Janas, K.M.; Posmyk, M.M. Melatonin, an underestimated natural substance with great potential for agricultural application. Acta Physiol. Plant. 2013, 35, 3285-3292. [CrossRef]

86. Sun, Q.; Zhang, N.; Wang, J.; Zhang, H.; Li, D.; Shi, J.; Li, R.; Weeda, S.; Zhao, B.; Ren, S.; et al. Melatonin promotes ripening and improves quality of tomato fruit during postharvest life. J. Exp. Bot. 2015, 66, 657-668. [CrossRef] [PubMed]

87. Sun, Q.; Zhang, N.; Wang, J.; Cao, Y.; Li, X.; Zhang, H.; Zhang, L.; Tan, D.X.; Guo, Y.D. A label-free differential proteomics analysis reveals the effect of melatonin on promoting fruit ripening and anthocyanin accumulation upon postharvest in tomato. J. Pineal Res. 2016, 61, 138-153. [CrossRef]

88. Karaca, P.; Cekic, F.Ö. Exogenous melatonin-stimulated defense responses in tomato plants treated with polyethylene glycol. Int. J. Veg. Sci. 2019, 1-9. [CrossRef]

89. Sakuraba, Y.; Schelbert, S.; Park, S.Y.; Han, S.H.; Lee, B.D.; Andres, C.B.; Kessler, F.; Hortensteiner, S.; Paek, N.C. STAY-GREEN and chlorophyll catabolic enzymes interact at light-harvesting complex II for chlorophyll detoxification during leaf senescence in Arabidopsis. Plant Cell 2012, 24, 507-518. [CrossRef]

90. Aiamla-or, S.; Nakajima, T.; Shigyo, M.; Yamauchi, N. Pheophytinase activity and gene expression of chlorophyll-degrading enzymes relating to UV-B treatment in postharvest broccoli (Brassica oleracea L. Italica Group) florets. Postharvest Biol. Technol. 2012, 63, 60-66. [CrossRef]

91. Sharma, A.; Yuan, H.; Kumar, V.; Ramakrishnan, M.; Kohli, S.K.; Kaur, R.; Thukral, A.K.; Bhardwaj, R.; Zheng, B. Castasterone attenuates insecticide induced phytotoxicity in mustard. Ecotoxicol. Environ. Saf. 2019, 179, 50-61. [CrossRef] [PubMed]

92. Sharma, A.; Kumar, V.; Yuan, H.; Kanwar, M.K.; Bhardwaj, R.; Thukral, A.K.; Zheng, B. Jasmonic Acid Seed Treatment Stimulates Insecticide Detoxification in Brassica juncea L. Front. Plant Sci. 2018, 9, 1609. [CrossRef]

93. Sharma, A.; Thakur, S.; Kumar, V.; Kanwar, M.K.; Kesavan, A.K.; Thukral, A.K.; Bhardwaj, R.; Alam, P.; Ahmad, P. Pre-sowing seed treatment with 24-epibrassinolide ameliorates pesticide stress in Brassica juncea L. through the modulation of stress markers. Front. Plant Sci. 2016, 7, 1569. [CrossRef] [PubMed]

94. Fleta-Soriano, E.; Díaz, L.; Bonet, E.; Munné-Bosch, S. Melatonin may exert a protective role against drought stress in maize. J. Agron. Crop Sci. 2017, 203, 286-294. [CrossRef]

95. Antoniou, C.; Chatzimichail, G.; Xenofontos, R.; Pavlou, J.J.; Panagiotou, E.; Christou, A.; Fotopoulos, V. Melatonin systemically ameliorates drought stress-induced damage in Medicago sativa plants by modulating nitro-oxidative homeostasis and proline metabolism. J. Pineal Res. 2017, 62. [CrossRef] [PubMed]

96. Li, C.; Tan, D.X.; Liang, D.; Chang, C.; Jia, D.; Ma, F. Melatonin mediates the regulation of ABA metabolism, free-radical scavenging, and stomatal behaviour in two Malus species under drought stress. J. Exp. Bot. 2015, 66, 669-680. [CrossRef]

97. Ding, F.; Wang, G.; Wang, M.; Zhang, S. Exogenous Melatonin Improves Tolerance to Water Deficit by Promoting Cuticle Formation in Tomato Plants. Molecules 2018, 23, 1605. [CrossRef] [PubMed]

98. Liu, J.; Wang, W.; Wang, L.; Sun, Y. Exogenous melatonin improves seedling health index and drought tolerance in tomato. Plant Growth Regul. 2015, 77, 317-326. [CrossRef]

99. Gao, W.; Zhang, Y.; Feng, Z.; Bai, Q.; He, J.; Wang, Y. Effects of Melatonin on Antioxidant Capacity in Naked Oat Seedlings under Drought Stress. Molecules 2018, 23, 1580. [CrossRef]

100. Jiang, M.; Zhang, J. Water stress-induced abscisic acid accumulation triggers the increased generation of reactive oxygen species and up-regulates the activities of antioxidant enzymes in maize leaves. J. Exp. Bot. 2002, 53, 2401-2410. [CrossRef]

101. Yang, W.J.; Du, Y.T.; Zhou, Y.B.; Chen, J.; Xu, Z.S.; Ma, Y.Z.; Chen, M.; Min, D.H. Overexpression of TaCOMT Improves Melatonin Production and Enhances Drought Tolerance in Transgenic Arabidopsis. Int. J. Mol. Sci. 2019, 20, 652. [CrossRef] [PubMed]

102. Zuo, B.; Zheng, X.; He, P.; Wang, L.; Lei, Q.; Feng, C.; Zhou, J.; Li, Q.; Han, Z.; Kong, J. Overexpression of MzASMT improves melatonin production and enhances drought tolerance in transgenic Arabidopsis thaliana plants. J. Pineal Res. 2014, 57, 408-417. [CrossRef] [PubMed] 
103. Li, J.; Zeng, L.; Cheng, Y.; Lu, G.; Fu, G.; Ma, H.; Liu, Q.; Zhang, X.; Zou, X.; Li, C. Exogenous melatonin alleviates damage from drought stress in Brassica napus L. (rapeseed) seedlings. Acta Physiol. Plant. 2018, 40, 43. [CrossRef]

104. Galano, A.; Tan, D.X.; Reiter, R.J. Melatonin as a natural ally against oxidative stress: A physicochemical examination. J. Pineal Res. 2011, 51,1-16. [CrossRef] [PubMed]

105. Reiter, R.J.; Tan, D.X.; Terron, M.P.; Flores, L.J.; Czarnocki, Z. Melatonin and its metabolites: New findings regarding their production and their radical scavenging actions. Acta Biochim. Pol. 2007, 54, 1-9. [PubMed]

106. Galano, A.; Tan, D.X.; Reiter, R.J. On the free radical scavenging activities of melatonin's metabolites, AFMK and AMK. J. Pineal Res. 2013, 54, 245-257. [CrossRef] [PubMed]

107. Foyer, C.H.; Halliwell, B. The presence of glutathione and glutathione reductase in chloroplasts: A proposed role in ascorbic acid metabolism. Planta 1976, 133, 21-25. [CrossRef]

108. Bela, K.; Horvath, E.; Galle, A.; Szabados, L.; Tari, I.; Csiszar, J. Plant glutathione peroxidases: Emerging role of the antioxidant enzymes in plant development and stress responses. J. Plant Physiol. 2015, 176, 192-201. [CrossRef]

109. Hell, R.; Bergmann, L. $\lambda$-Glutamylcysteine synthetase in higher plants: Catalytic properties and subcellular localization. Planta 1990, 180, 603. [CrossRef]

110. Subbarao, G.; Chauhan, Y.; Johansen, C. Patterns of osmotic adjustment in pigeonpea-Its importance as a mechanism of drought resistance. Eur. J. Agron. 2000, 12, 239-249. [CrossRef]

111. Signorelli, S. The Fermentation Analogy: A Point of View for Understanding the Intriguing Role of Proline Accumulation in Stressed Plants. Front. Plant Sci. 2016, 7, 1339. [CrossRef] [PubMed]

112. Verbruggen, N.; Hermans, C. Proline accumulation in plants: A review. Amino Acids 2008, 35, 753-759. [CrossRef]

113. Zhang, L.; Xi, D.; Li, S.; Gao, Z.; Zhao, S.; Shi, J.; Wu, C.; Guo, X. A cotton group C MAP kinase gene, GhMPK2, positively regulates salt and drought tolerance in tobacco. Plant Mol. Biol. 2011, 77, 17-31. [CrossRef] [PubMed]

114. Wang, J.; Zhang, L.; Cao, Y.; Qi, C.; Li, S.; Liu, L.; Wang, G.; Mao, A.; Ren, S.; Guo, Y.D. CsATAF1 Positively Regulates Drought Stress Tolerance by an ABA-Dependent Pathway and by Promoting ROS Scavenging in Cucumber. Plant Cell Physiol. 2018, 59, 930-945. [CrossRef] [PubMed]

115. Hoang, X.L.T.; Nhi, D.N.H.; Thu, N.B.A.; Thao, N.P.; Tran, L.P. Transcription Factors and Their Roles in Signal Transduction in Plants under Abiotic Stresses. Curr. Genom. 2017, 18, 483-497. [CrossRef] [PubMed]

116. Rennenberg, H.; Loreto, F.; Polle, A.; Brilli, F.; Fares, S.; Beniwal, R.S.; Gessler, A. Physiological responses of forest trees to heat and drought. Plant Biol. 2006, 8, 556-571. [CrossRef]

117. Huang, L.; Li, M.; Zhou, K.; Sun, T.; Hu, L.; Li, C.; Ma, F. Uptake and metabolism of ammonium and nitrate in response to drought stress in Malus prunifolia. Plant Physiol. Biochem. 2018, 127, 185-193. [CrossRef]

(C) 2019 by the authors. Licensee MDPI, Basel, Switzerland. This article is an open access article distributed under the terms and conditions of the Creative Commons Attribution (CC BY) license (http://creativecommons.org/licenses/by/4.0/). 